\title{
Biochemical indices of osteomalacia in pregnant Asian immigrants in Britain
}

\author{
A. T. HOWARTH \\ From the Department of Biochemistry, Royal Infirmary, Bradford
}

SYNOPSIS Serum calcium, phosphate and alkaline phosphatase, and urinary calcium excretion were examined during the second trimester of uncomplicated normal pregnancy in Asian immigrants to Britain and in local Caucasians. The mean serum calcium was significantly lower in Asians than in Caucasians, and the mean serum alkaline phosphatase was significantly higher in Asians. The geometric mean of the urinary calcium excretion was highly significantly lower in Asians than in Caucasians. The variances of the serum calcium, serum alkaline phosphatase, and urine calcium excretion did not differ significantly in the two populations. This indicates that there is a shift in values of immigrant Asians as a group compared with Caucasians. A comparison with figures obtained on normal nonpregnant persons of both groups suggests that the shift is not an inherent feature of the Asian population.

A high prevalence of osteomalacia exists among children of Asian immigrants. Preece et al (1973) estimated its frequency at about $10 \%$ and thought that biochemically the disorder may be even more common, perhaps about $25 \%$ if all ages were considered. Some acute cases occur in mothers in late pregnancy or in the early postnatal period. Watney and Rudd (1974), in their study, noted that most pregnant women have biochemical changes tending towards osteomalacia and that this particularly affects Asians.

In the present study blood and urine samples from pregnant women were examined for biochemical evidence of osteomalacia. It was hoped that early detection of likely sufferers would allow prophylactic treatment with the object of preventing development of serious clinical abnormalities. This study indicates that this early selection of individuals proved impractical on biochemical evidence. Women in the second trimester of normal uncomplicated pregnancy were studied. As significant differences in the concentration of many body constituents occur during pregnancy, a precisely similar series of pregnant local Caucasians was studied for comparison. It was anticipated that serum calcium, phosphate, alkaline phosphatase, and urinary calcium would show a similar distribution with similar mean values in both populations but that a skewness or bimodal distribution would be demonstrable in the Asian group

Received for publication 7 April 1976 due to the higher frequency of abnormal values from cases of osteomalacia. For the purposes of comparison the same 'parameters were determined in a large number of 'normal' nonpregnant Caucasians and Asians.

\section{Methods}

The samples were obtained from a random series of healthy normal pregnant women attending a clinic for routine antenatal examination. The series of nonpregnant people was obtained by selecting patients who were attending hospital as either inpatients or outpatients for conditions in which those constituents are not known to be affected, for example, haematology outpatients, skin disease patients, etc.

Calcium analyses were performed by an automated cresolphthalein complexone technique. Inorganic phosphate was determined by an automated version of the phosphomolybdate method. Albumin was determined by the automated bromocresol green method. Alkaline phosphatase estimations were made using the p-nitrophenol phosphate technique. AutoAnalyzer equipment (Technicon Instrument Co, Tarrytown, New York) was used in each case.

Serum calcium concentrations were adjusted for albumin concentration using the formula of Payne et al (1973), viz, adjusted calcium = calcium $(\mathrm{mmol} / \mathrm{l})-(0.025 \times$ albumin $\mathrm{g} / \mathrm{l})+1$; adjusted calcium $(\mathrm{mg} / 100 \mathrm{ml})=$ calcium $(\mathrm{mg} / 100 \mathrm{ml})-$ albumin $(\mathrm{g} / 100 \mathrm{ml})+4 \cdot 0$. Normal probability plots 
were made to determine whether the data best fitted a Gaussian or a log-Caussian distribution, and logarithmic transformation was used when appropriate in calculating means and $95 \%$ confidence limits. The mean values for the Caucasian women were then compared with those for the Asian women by means of the $t$ test. The variances were compared by means of the $F$ test.

\section{Results}

The results are presented in the table.

\section{Discussion}

The results showed that, contrary to expectation, the variance of the distribution for each of the substances studied, apart from phosphate, was similar in the two racial groups. Caucasians have no significant incidence of osteomalacia but the incidence among nonpregnant Asians is high; Preece et al (1973) found it to be about $25 \%$ when judged by Caucasian criteria including biochemical data. It was expected to be higher, if anything, in the pregnant group studied here as the demand for calcium by the fetus is high. They attributed the low vitamin D (25 hydroxy cholecalciferol) in the serum of Asians to their low dietary intake and thought that this was responsible for Asian osteomalacia. It may well be inadequate to allow sufficient extra calcium absorption to cope with the extra demands of pregnancy. The fact that the variances were the same for both pregnant groups is thus surprising. The significant difference between the distribution of the Caucasian and Asian values was in their location rather than in their shape, that is, they had different mean values. The mean serum calcium $\frac{0}{\vec{*}}$ in Asians was significantly lower by $0.10 \mathrm{mmol} / \mathrm{l}, \frac{\mathrm{O}}{\mathrm{N}}$ $(0.41 \mathrm{mg} / 100 \mathrm{ml})$ than in Caucasians. The geometric $\overrightarrow{\vec{F}}$ mean serum alkaline phosphatase was significantly higher by $3.4 \mathrm{KA}$ units per $100 \mathrm{ml}$ than in Caucasians. The geometric mean urinary calcium excretion $\frac{\bar{\sigma}}{\overline{0}}$ was highly significantly lower in Asians by $2.95 \frac{}{\circ}$ $\mathrm{mmol} / 24 \mathrm{hr}(118 \mathrm{mg} / 24 \mathrm{hr})$. Although we found that $\varnothing$ these constituents had different levels in the two o populations, the fact that the variances were the same $\overrightarrow{0}$ means that we cannot distinguish Asians with osteomalacia from Asians without osteomalacia $\vec{\omega}$ using biochemical criteria applied in Caucasians. The whole Asian population studied had moved on ? average equally toward what would be considered a 응 biochemical state of osteomalacia. Whatever the cause it had affected the whole population equally $\overrightarrow{0}$ and not just a proportion who might be expected to $\stackrel{\infty}{\rightarrow}$ develop clinical symptoms. The figures for serum 을 inorganic phosphate also showed a significant difference between the mean values for Caucasians $z$ and Asians, the latter being $0.08 \mathrm{mmol} / \mathrm{l}(0.19 \mathrm{mg} / 100$ $\mathrm{ml})$ higher. In this case, however, there was a significant difference in the variances, there being a signifi- $\mathcal{\Phi}^{\circ}$ cantly wider spread in the curve on both sides of the mean for the Asians. No explanation for this 8 apparent.

That these facts were not due to some peculiari of the group of patients selected for this study was shown by applying the technique to studies by other authors. Preece et al (1973) reported on the serum 25 hydroxy-cholecalciferol of Asians and Caucasians. Their data showed logarithmic distributions. The geometric means were $2.7 \mathrm{ng} / \mathrm{ml}$ for Asians and 10.8 $\mathrm{ng} / \mathrm{ml}$ for Caucasians. This difference in mean is

\begin{tabular}{|c|c|c|c|c|c|c|c|}
\hline & \multirow[t]{2}{*}{$N$} & \multicolumn{2}{|c|}{ Pregnant Caucasians } & \multicolumn{2}{|c|}{ Pregnant Asians } & \multirow{2}{*}{$\begin{array}{l}\text { P value of } \\
\text { t test } \\
\text { between } \\
\text { means }\end{array}$} & \multirow{2}{*}{$\begin{array}{l}\text { P value of } \\
\text { F test of } \\
\text { variances }\end{array}$} \\
\hline & & Mean & $95 \%$ confidence limits & Mean & $95 \%$ confidence limits & & \\
\hline $\begin{array}{l}\text { Serum calcium (mmol/1) } \\
\text { Serum calcium adjusted for albumin }\end{array}$ & 110 & $2 \cdot 28$ & $2 \cdot 08-2 \cdot 50$ & $2 \cdot 18$ & $1 \cdot 98-2 \cdot 43$ & $<0.001$ & $>0.05$ \\
\hline $\begin{array}{l}\text { level (mmol/l) } \\
\text { Serum phosphate (mmol/1) } \\
\text { Serum albumin }(\mathrm{g} / \mathrm{l})\end{array}$ & $\begin{array}{l}110 \\
110 \\
110\end{array}$ & $\begin{array}{l}2 \cdot 36 \\
1 \cdot 01 \\
36 \cdot 9 \\
\text { Geom. } \\
\text { Mean }\end{array}$ & $\begin{array}{l}2 \cdot 15-2 \cdot 55 \\
0 \cdot 76-1 \cdot 27 \\
31-43\end{array}$ & $\begin{array}{l}2 \cdot 30 \\
0 \cdot 93 \\
36 \cdot 0 \\
\text { Geom. } \\
\text { Mean }\end{array}$ & $\begin{array}{l}2 \cdot 08-2 \cdot 53 \\
0 \cdot 52-1 \cdot 38 \\
30 \cdot 8-41 \cdot 1\end{array}$ & $\begin{array}{l}<0.001 \\
<0.01 \\
<0.01\end{array}$ & $\begin{array}{l}>0.05 \\
<0.05 \\
>0.05\end{array}$ \\
\hline $\begin{array}{l}\text { Serum alkaline phosphatase (K A } \\
\text { units } / 100 \mathrm{ml} \text { ) } \\
\text { Urine calcium (mmol } / 24 \mathrm{hr} \text { ) }\end{array}$ & $\begin{array}{l}110 \\
110\end{array}$ & $\begin{array}{l}8 \cdot 2 \\
5 \cdot 35\end{array}$ & $\begin{array}{l}4 \cdot 3-15 \cdot 7 \\
1 \cdot 48-19 \cdot 3\end{array}$ & $\begin{array}{r}11 \cdot 6 \\
2 \cdot 40\end{array}$ & $\begin{array}{l}5 \cdot 6-23 \cdot 4 \\
0 \cdot 50-11 \cdot 1\end{array}$ & $\begin{array}{l}<0.001 \\
<0.001\end{array}$ & $\begin{array}{l}>0.05 \\
>0.01\end{array}$ \\
\hline $\begin{array}{l}\text { Calcium (mmol/1) } \\
\text { Serum phosphate (mmol/l) } \\
\text { Serum albumin (g/litre) } \\
\text { Serum alkaline phosphatase (K A } \\
\quad \text { units } / 100 \mathrm{ml} \text { ) }\end{array}$ & $\begin{array}{l}140 \\
140 \\
140 \\
140\end{array}$ & $\begin{array}{r}2 \cdot 30 \\
1 \cdot 05 \\
42 \cdot 26 \\
8 \cdot 0\end{array}$ & $\begin{array}{l}\text { Normal non-pregnant } \\
1.9-2.68 \\
0.7-1 \cdot 4 \\
35-49\end{array}$ & $\begin{array}{c}\text { persons } \\
2 \cdot 29 \\
1 \cdot 08 \\
42 \cdot 43 \\
8.6\end{array}$ & $\begin{array}{l}2 \cdot 1-2 \cdot 5 \\
0 \cdot 6-1 \cdot 5 \\
35-50\end{array}$ & $\begin{array}{l}>0.05 \\
>0.05 \\
>0.05 \\
>0.01\end{array}$ & $\begin{array}{l}>0.05 \\
>0.05 \\
>0.05 \\
>0.05\end{array}$ \\
\hline
\end{tabular}

Table Statistical comparison of parameters in the different racial populations 
highly significant but the variances calculated from the logarithms of the values show no significant difference.

A paper on calcium metabolism in pregnancy and in the newborn by Watney and Rudd (1974) quotes figures for serum calcium levels in Caucasians and Asians. The mean values quoted for 29 weeks' gestation compare directly in time with the sample in this series. Again the means were significantly different, being $2.29 \mathrm{mmol} / 1 \quad(9.16 \mathrm{mg} / 100 \mathrm{ml})$ for Caucasians and $2.25 \mathrm{mmol} / 1(9.00 \mathrm{mg} / 100 \mathrm{ml})$ for Asians, but the variances were not significantly different. The figures for inorganic phosphate were similar to the ones reported here, showing a significant difference in both means and variances. Their figures for calcium might be subject to the criticism that they had not been adjusted for albumin concentration. The present figures were corrected in this way and show that the difference in mean calcium concentration is not due to differences in albumin concentration.

Presumably subjects with values at the more abnormal ends of the 'normal distribution' have lowered calcium absorption to a degree which results in clinical osteomalacia. The actual values for urine calcium are interesting and are the subject of another communication. The demonstration that the values for these constituents are shifted in the direction of biochemical osteomalacia in pregnant Asian women has two possible interpretations:

1 that this reveals an abnormality, the correction of which should bring the values for Asians into the same range as those for Caucasians;

2 that the difference between the two is a genuine difference between the two racial groups, viz, that 95\% confidence limits for substances differ in Asians from Caucasians, when both groups are in normal good health.

It was to ascertain which of these explanations was. the correct one that the series of values on 'normal' nonpregnant Caucasians and Asians was collected. From the results we see that in these 'normal' persons there is no significant difference between the means of these substances in the two racial groups. It follows that the difference revealed by this study is an abnormality which presumably should be capable of correction by administration of vitamin $\mathrm{D}$, etc, as suggested by Watney and Rudd (1974). As we are unable to select individuals particularly at risk, the treatment should be applied to the whole Asian group, possibly by advising them to eat margarine fortified with vitamin D. Even so we have no unequivocal proof that positive benefit would ensue from prophylactic treatment. Studies such as that reported here are very necessary as the situation has not changed significantly since 1965 when the World Health Organization reported that it 'wished to emphasize that the areas of ignorance relating to nutrition in pregnancy and lactation are extremely large and that it is impossible as a rule to state didactically that this or that particular form of dietary change will produce a specific effect'.

My thanks are due to Dr R. B. Payne of St James (University) Hospital Leeds for helpful advice and criticism.

\section{References}

Payne, R. B., Little, A. J., Williams, R. B., and Milner, J. R. (1973). Interpretation of serum calcium in patients with abnormal serum proteins. Brit. med. J., 4, 643-646.

Preece, M. A., Ford, J. A., McIntosh, W. B., Dunnigan, M. G., Tomlinson, S., and O'Riordon, J. L. H. (1973). Vitamin-D deficiency amongst Asian immigrants to Britain. Lancet, 1, 907-910.

Watney, P. J. M. and Rudd, B. T. (1974). Calcium metabolism in pregnancy and in the newborn. J. Obstet. Gynaec. Brit. Cwlth., 81, 210-219.

World Health Organization (1965). Nutrition in pregnancy and lactation. Wld. Hlth. Org. techn. Rep. Ser., 302. 